\title{
GENDER IMPACT ON PERSONAL INVESTMENT STRATEGIES
}

\author{
Mintautė Mikelionyte் ${ }^{1}$, Aleksandra Lezgovko \\ ${ }^{1}$ Vilnius Gediminas Technical University, Vilnius, Lithuania; e-mail: mintaute.mikelionyte@gmail.com \\ ${ }^{2}$ Vilnius Gediminas Technical University, Vilnius, Lithuania; e-mail: aleksandra.lezgovko@gmail.com
}

\begin{abstract}
Research purpose. This study is dedicated to investigating the peculiarities of personal investment decisions among female and male investors to analyse the gender differences that occur during personal investment strategy establishment processes. This study is based on the literature research and aims at exploring the existing knowledge on financial behaviour and gender influence on personal investment selection. The importance and originality of this study are that it assesses the collective evidence in the personal investment field and explores its processes through the prism of gender impact. The understanding of the gender bias impact on the personal investment strategy development process can play an important role in addressing the issue of gender inequality in finance and investment areas. This paper is dedicated to answering the question of how gender impacts personal investment strategies.
\end{abstract}

Design/ Methodology/ Approach. The major task was to conduct the research on the male and female personal investment decision peculiarities presented in literature sources and to prepare the survey to conduct practical research while applying theoretical knowledge and presenting the findings along with the suggestions on how to improve the female situation in investment field.

Findings. The most prominent finding to emerge from this study is that females lack knowledge and understanding in finance and especially investment areas; therefore, this leads to inadequacy in self-confidence in finance and investment matters and, as a result, neglect of successful personal finance management and, more significantly, poor investment strategy decisions.

Originality/ Value/ Practical implications. The main goal of the current study was to determine whether the gender difference exists in personal finance and especially investment area, to refine the reasons behind this phenomenon, to analyse what could be done to improve the situation and introduce suggestions for further research. The research was done based on relevant literature, reports, surveys, statistical data used for literature analysis, and Lithuania's case study for the practical part of the research. The primary objectives were to find out what are the main peculiarities between males and females when it comes to personal investment strategy choices and to analyse financial literacy and investment fields through the female perspective. The main points revealed during this study were that men tend to invest more often than women, as females, in general, prefer to save rather than invest; women tend to choose less risky investment strategies compared to men or save rather than invest. The main factors of this phenomena are the influence of cultural, social, or psychological factors, low financial literacy level, differences in economic status, longer life expectancy, the lack of confidence when it comes to knowledge applied to the financial decisions; males are more likely to choose a higher-risk investment strategy and to be more confident in their investment ability even if they have less knowledge on the matter. The analysis of Lithuania's case has also confirmed the main literature review findings and reported females to lack financial and investment knowledge, spare funds and prefer to save rather than invest or invest into the low-risk tools.

Keywords: Investment strategy; Personal investment strategy; Investment decision; Investment risk; Gender difference; Female investing.

JEL codes: G23, G53. 


\section{Introduction}

There is a growing body of literature that recognises the importance of investment processes based on the sacrifice of a certain present value for the uncertain future returns, and many of us choose to invest to get an additional source of income by gaining profit. Every investor models a personal investment strategy applying a unique technique, and it was established in various literature sources (Stanyer \& Satchell, 2018; Walker \& Walker, 2013; Malkiel, 2019; Farrell, Fry, \& Risse, 2016; Shaikh, Karim Katpar, Kalhoro, Abro, \& Phanwar, 2019) that this practice could be based on a several of influencing factors such as the number of funds that could be dedicated for investment purposes, the goals that are set, the desired returns, the applicable time frame, etc. As the right strategy assures the highest profit, accordingly one of the fundamental goals to achieve by the investor is to develop the most successful personal investment strategy that would include the primary investment management aspects such as setting investment objectives, establishing an investment policy, selecting an investment strategy, selecting the specific assets, and measuring and evaluating investment performance.

Recent evidence suggests that women tend to invest less compared to men (Jawaheer \& Manual, 2016; Farrell, Fry, \& Risse, 2016; Charness \& Gneezy, 2007). This is related to even more significant discovery that has been introduced by many other authors, global surveys and financial reports (Tengler, 2014; Levine, 2019; Itkin, 2014; The Standard \& Poor's Ratings Services, 2015, Australian Security Exchange, 2020), which states that women tend to have less knowledge about finances in general and particularly investment processes; hence, it leads to their lack of interest in investment field and the possibility of poor money management. Many behavioural finance and gender doctrines experts attribute these inequalities to behavioural biases. They claim that it is due to the gender differences as female investors appear both to be more risk-averse and to have less confidence in their investment decisions than male (Dickason, Nel \& Ferreira, 2017; Hussain, et al., 2015; Lee, Miller, Velasquez \& Wann, 2013). The other researchers associate this phenomenon with insufficient financial literacy level among females (Hasler \& Lusardi, 2017; The Standard \& Poor's Ratings Services, 2015, Australian Security Exchange, 2020). This, among many other inequalities, to name a few, pay gap, unpaid work, or lack of balance in managing positions at the workplace, creates the investment and wealth generation gap among men and women. Since females generally live longer (World Health Organization, 2018), their retirement period is increases accordingly, and by not investing or choosing less risky, and therefore, less profitable investment tools, women deprive themselves of possible additional profits of around 6 to 8 years compared to male investors. The facts provided above confirm the significance and possible positive impact of women beginning to invest or adjusting current personal investment strategies to improve their financial situation and earn additional funds.

The combination of negative impacts mentioned above and the tendency to invest in small risk and low returns investment option indicates one of the possible reasons for the wealth inequality among genders and the possible place for improvement in investment field among females. This is an important issue for further research, and the leading suggestions would be to concentrate on female education and respective financial and investment programs creation to improve the current situation by creating the method to encourage women to invest more and not to limit themselves by safe investment tools, but to create broader diversified personal investment strategies with the inclusion of bearing higher-risk, subsequently, benefiting greater returns investing instruments. However, as represented by this paper, first, the emphasis should be placed on introducing and explaining a wider variety of investment instruments to females. This could also be done by introducing an example portfolio that would be created based on individual needs. To achieve this, the target groups, for example, based on age, need to be indicated, and the preliminary personal investment strategy could be adapted accordingly. The examples of the countries with well-developed female investment and finance areas could be applied as a good practice method and used by the less advanced countries. More information on female personal investment strategy formulation peculiarities would help us establish a greater degree of accuracy on this matter. 
Therefore, the study conducted during this article aims to research why the differences among female and male investors appear first and, based on the findings, suggests how females could be motivated to invest more actively; hence, how the gender inequality gap in investment area could be decreased. To answer this question, the research on available literature was conducted, and it revealed the fundamental characteristics of men and women personal investment strategies decisions. The biggest limitation that appeared during the data collection for this article was the lack of more profound and more concentrated relevant information; hence, the lack of surveys or research on the personal investment strategies among female and male investors.

\section{Literature Review}

According to many authors, global surveys, and financial reports (Tengler, 2014; Levine, 2019; Itkin, 2014; The Standard \& Poor's Ratings Services, 2015, Australian Security Exchange, 2020), women tend to have less knowledge about finances in general and particularly investment processes; hence, it leads to their lack of interest in investment field and the possibility of poor money management. Many behavioural finance and gender doctrines experts attribute these inequalities to behavioural biases. They claim that it is due to the gender differences as female investors appear both to be more risk-averse and to have less confidence in their investment decisions than male (Dickason, Nel \& Ferreira, 2017; Hussain, et al., 2015; Lee, Miller, Velasquez \& Wann, 2013). The other researchers associate this phenomenon with insufficient financial literacy level among females (Hasler \& Lusardi, 2017; The Standard \& Poor's Ratings Services, 2015, Australian Security Exchange, 2020). Based on the literature review and findings, the assumption could be made that this is rather the combination of a variety of reasons, and the ultimate correct answer does not exist.

Due to savings accounts, real estate, pension funds, bonds and similar investment options providing lower returns and being considered low risk, combined with the discoveries on male and female investment behaviour peculiarities presented in this section, it should be assumed that women would prefer the less risky type of investment tools. Viewed in this way, female investment choices could generate low returns, and the reasons behind these investment decisions might be gender-specific behavioural biases.

One major theoretical issue that has dominated the field for many years concerns whether gender can influence personal investment strategy. It is now well established from a variety of financial behavioural studies (Stanyer \& Satchell, 2018; Walker \& Walker, 2013; Malkiel, 2019; Farrell, Fry, \& Risse, 2016; Shaikh, Karim Katpar, Kalhoro, Abro, \& Phanwar, 2019) that the investors are not rational and that female investment decisions differ from those of a male. The success and the number of returns of the investment essentially depend on the performance of the choice the investor made, and since the decision is influenced by the gender factor, which leads to the declaration that women and men tend to invest differently, their personal investment strategies are dissimilar. Many researches revealed that women tend to invest less and in less profitable but safer investment tools, consequently, gain less profit from the investment (Farrell, Fry, \& Risse, 2016).

It is important to identify the main differences between male and female personal investment strategies to figure out why this phenomenon occurs and how to encourage women to invest more, and by doing this, to increase the profit from their investments and, accordingly, accumulate more wealth. By finding the answers to these questions, the suggestions could be presented on how to solve the wealth inequality problem between genders, which is directly related to the investment process and particularly has a major impact on the decision-making process of the personal investment strategy. A number of papers and books have been written, researches have been conducted, and the outcomes that were presented show the importance and relevance of the topic. For instance, one of the studies that was conducted in the USA has shown that gender influences investment decision-making in three ways: risk, confidence, and preferences (Hira \& Loibl, 2008). A couple of more studies regarding the same topic was conducted in Australia by the government, and the major discoveries were that women tend to choose the less risky investment strategies and the most popular between all of them were savings account, which is paying 
highest interest rates; men are more likely to choose the higher risk investment strategy and to be more confident in their investment ability even if they have less knowledge on the matter; women and men choose to buy their own homes instead of renting and this fact reveals that both of the genders tend to invest in real estate, rather than rent it (Australian Government Financial Literacy Foundation, 2008a, 2008b; Australian Securities and Investment Commission, 2008; Mottola, 2015). The research related to the female and male investment decision differences have been conducted in Lithuania as well, and the key findings of these articles showed that Lithuanian men tend to invest more, whereas women choose to save instead. Additionally, females were found to plan their finances ahead and know more details on how much spend daily than males. In addition, the studies have shown that men choose to invest in riskier portfolios than women (INVL Asset Management, 2018; Macijauskas, 2012).

The research discussed in this section revealed significant differences between gender personal investments selections:

- Risk acceptance.

- Confidence level.

- Preferences.

This section of the article establishes and presents the evidence that the strong relationship between gender and risk perception, confidence and investment decisions have been indicated and reported in the scientific literature, surveys, and other research on the personal investment area. It seems to be possible that these results are due to the previously established gender biases and differences that appear in the investment area.

The risk factor, as one of the most important aspects that influence any investment, seems to be highly relevant to the female and male investment decision making as well. Many authors have been studying and discussing the importance that risk element has in female investor's choice of the investment tool. The findings show that the risk segment plays the major role in women's personal investment strategy planning, and it tends to be the lower level than in men investment choices: "women make smaller investments in the risky asset than men do, and so appear to be financially more risk-averse $<\ldots>$ women's portfolios are less risky than men's (Charness \& Gneezy, 2007), they tend to be more conservative while investing and generally have a preference for low-risk securities $\langle\ldots>$ They are more likely to choose fixed income securities (Mittal \& Vyas, 2009). Based on the ideas presented in these articles, the assumption could be made that the main difference between women and man investing choices and style when it comes to risk level is that females choose the lower risk investment options than males. The literature review revealed that women are more risk-averse than men and choose more conservative personal investment options. Since the lowest risk investment strategies are such as savings account, deposit, bonds, real estate or pension fund, the prediction could be made that women most likely should choose these types of investment strategies. Whereas men, as exclaimed in the articles, tend to be able to accept the higher risk level in relation to investment choices. This leads to the assumption that men choose the riskier investment options such as stocks, shares, various funds and others.

Discussing the role of the risk in the investing process in their article Bayyurt, Karışık, \& Coşkun introduce four main ideas why risk acceptance differs so drastically between genders:

- It was found that women and men may differ in their underlying attitudes or utility functions for risk. Cultural, social, or psychological factors may cause men to bear more risk than women.

- Gender differences in risk-bearing might be due to differences in economic status.

- Women's longer life expectancy and a greater probability of outliving their spouses could affect their willingness to accept financial risk.

- Gender differences in risk-taking may occur due to gender differences in information and confidence in their financial knowledge.

Perhaps every advocate of Behavioural Finance theory would agree that one's psychological and personal traits, as well as the influence of social and cultural aspects, affect the possibility to bear the 
risk and accordingly to make the choice of the investment option. The ideas of Oprean could be presented as an elaboration on this statement: "The most common human traits (fear, anger, greed, and selflessness) place considerable emphasis on our decisions about the money. Intellect (grasping a situation), the reason (long-term consequences of the action taken) and emotion (considering a course of action) are all interrelated; they are the springs behind the human decision" (Oprean, 2014). This statement also has been explained by looking from a psychological point of view. It has been researched why females tend to choose lower-risk investments than men and stated that the reason behind this behaviour is women having more of the enzyme "monoamine oxidase", which prevents them from seeking amplified sensations, which suggests that they would prefer less risk since it is less stressful (Felton, Gibson, \& Sanbonmatsu, 2003).

The second statement leads to the topic, which is highly relevant nowadays, and it refers to the economic status difference between genders and the pay gap. It is a known fact that females tend to earn less than men. For instance, the Statistics of Lithuania presented the research finding called "Women and men in Lithuania 2016". The key findings related to the pay gap and economic wealth differences between genders are that women tend to earn less than men and the pay gap was 14.4\% in 2016 (Statistics of Lithuania, 2017). Besides, in the USA females earn 77.9 cents for every dollar that men earn, and it was around a 23\% wage gap in 2018 (PayScale, 2018). Additionally, the statistics show that overall, in the European Union, the pay gap between genders was $16.2 \%$ (N. McCarthy, N. McCarthy \& Richter, 2018). This data provides an explanation of why the lower risk acceptance level is possible for female investors. The reason is the lower wage, and accordingly, the loss of the investment becomes a more significant risk as women earn less, they can afford to lose less.

According to statistics presented by the World Health Organization in 2016, the life expectancy was 72.0 years (74.2 years for females and 69.8 years for males) (World Health Organization, 2018). Consequently, women tend to live longer than men, and while creating the personal investment strategy, they must take this fact into consideration in order to be able to ensure a financially stable future. Due to women's greater longevity, less wealth will have to support a longer retirement, resulting in a disparity between retired men and women (Mittal \& Vyas, 2009).

Confidence is one of the major aspects of the investment decision-making process, and, unfortunately, it appears that mainly female investors tend to have less self-confidence than men. The research took place in the USA and was done to examine the situation of female financial behaviour, particularly concentrating on measuring how women address their finances, what the reasons they for them holding back and not being fully engaged are and how to improve the situation. The revelations of the study were presented in the report, and the key findings were that women are keen on gaining more knowledge about finances, want to learn more about financial planning, money and investment, and get more involved in their finances, yet the majority of them hold back when it comes to discussing money and finances, especially investment, and the leading factor of this issue is lack of confidence with additional deficiency of knowledge and experience in the finance area (Fidelity Investment, 2015). As Siva (2012) found in his research, "Women are more calculative, less confident, less aggressive, and easier to persuade and have inferior leadership and problem-solving abilities when making a decision under risk".

While risk and confidence play a major role in the personal investment strategy creation process, there are more important factors that affect the investment choices and are quite vivid between genders in the selection process. It is important to take into consideration the pay gap and employment inequality, the fact that the higher positions in a workplace tend to be occupied by men, that the women tend to be less confident when it comes to investment and overall financial matters, longer life expectancy of women, and that women are more likely to have to take care of their kids and overall family and, henceforth, the fewer recourses are left to be invested (European Union, 2018; Uited Nations, 2017; Ravazzini \& Kuhn, 2018; Brown \& Patten, 2018). The other authors have described the importance of women's personal investment strategy, with the primary focus on retirement as: "Women have lower lifetime earnings, lower earnings growth, lower wealth, and lower pension coverage and participation rates. Women's greater longevity implies that, even with the same investment strategy and pension accumulation, retirement wealth must support a longer period of retirement." (Bajtelsmit, Bernasek, 1997). These 
authors have pointed out the main factors that influence women's personal investment choices and answered the question, why women tend to choose the less risky investments than men. The presented factors could be considered as the key aspects for female investor preferences when it comes to personal investment strategy and future planning.

\section{Research Methodology}

To begin with, before choosing the right investment strategy, it is important to determine the method which would assist with evaluating the current personal financial situation, setting the goals, and creating the investment plan. (Tyson, 2019; Birtch, Au, Chiang, \& Hofman, 2018; Gerrans, Moulang, Feng, \& Strydom, 2018). While choosing the investment tool, it is essential to know what options are presented for selection in the financial market and which one is the most applicable to the investor. As an example, one can take such financial institutions as Nasdaq, Economy Watch, Westpac and National Australia Bank summary of explanations on the investment strategies choices (Nasdaq, 2019; National Australian Bank Limited, 2018; Economy Watch, 2018; Westpack banking corporation, 2018) Based on these sources the development of the personal investment strategy should involve such steps as:

- Specification of personal investment objective.

- Setting the timeframe.

- Asset allocation which involves diversification among asset classes that may protect the investments against underperformance in any one asset class.

- The decision of the investment that will be made.

- Must have a risk management plan in which identification of the risks for the chosen investment strategy and the plan on how to mitigate those risks should be presented.

- The information and assistance should be assessed. Some of the tools available to do this are company research and stock recommendations, charting and technical analysis, economic research, news services, watch lists and alerts, financial planners, or adviser's assistance.

In the current economic situation, people are gradually more often becoming investors to gain profit, to get the additional source of income and thus to secure their future. The main aim of every investor is to increase the income and value of the returns while minimising the risk of loss. To achieve this goal, such authors as Swenson (2005) and Malkiel (2019) in their books stated that it is important to create an investment strategy that would be based on investor's goals, resources, willingness to take risks and the length of the growth objectives. The investment strategy is like a systematic plan to allocate investable assets among different investment options; however, to be able to choose the most acceptable personal investment strategy, the individual has to have the additional amount of assets, preferably liquid funds, which would be dedicated to investment purposes. In addition to this, the investable assets should be allocated among the investment options considering the investor's tolerance level to the risk, the age, and the objectives, that the investor wishes to achieve. Consequently, to be able to make the most paramount decision in investment strategy alternative, a thorough analysis of the investment options has to be done, and the arguments for and against each of them have to be introduced.

Many authors share the same opinion that the most popular investment instruments (Liem \& McInerney, 2018; Huang, 2018; Lei, 2018) could be distinguished as follows:

- Savings account.

- Shares and stocks.

- Bonds.

- Investment funds.

- Pension funds.

- Real estate.

It is significant to know the main peculiarities of the investment strategies before making the final decision on which investment tool to select. 
This research has been conducted to find out the fundamental investment strategies and their tendencies and to compare the differences among female and male investors; and the methodology contains two main stages. The first stage - the data collection initiation, and the second stage is the analysis of the data and presentation of findings for further step - optimal portfolio formation.

The best method to collect data for public and sociologic research is a survey, and for the economic research area the best approach is statistical data analysis (Saris \& Gallhofer, 2014). To satisfy these requirements and to gather data for female investment strategy management, a quantitative research survey dedicated to collecting statistics of female investing peculiarities has been created. The most substantial part of collecting accurate data for this study is to clarify and implement the questionnaire's components precisely. The main segments included in the survey are sampling, question design, mode of data collection, and total survey design (Fowler, 2014). Considering previously mentioned details of questionnaire formation, the respondents' sample size has been calculated, based on the Slovin's formula (Mclean, Guilford, \& Fruchter, 1979):

$$
n=\frac{N}{\left(1+N e^{2}\right)}
$$

Where:

$\mathrm{n}=$ Number of samples

$\mathrm{N}=$ Total population

$\mathrm{e}=$ Error tolerance (level).

The sample calculation returns the result are as follows:

$\mathrm{n} \sim 100$

$$
n=\frac{1500000}{\left(1+1500000 * 0,1^{2}\right)}
$$

The relative question to the topic has been prepared and presented in five different forms:

- Dichotomous questions (Yes/No).

- Open-ended questions.

- Multiple choice questions.

- Ranking questions.

- Matrix questions.

The questions included in the questionnaire are as follows:

- On a scale of 1 to 5, how much knowledge do you have about investment and finances?

- Have you taken any courses, classes or any other kind of education related to investment/economics (please shortly describe if you have)?

- Do you plan your savings?

- How much do you save every month?

- On a scale of 1 to 5, evaluate the importance of the saving factors below (1 being the highest and 5 being the lowest importance): Financially stable retirement, Investing, "Rainy day", Kids' education, Leisure.

- Do you invest?

- Where do you invest?

- What, in your opinion, is the most important information to know in order to be able to invest 
- Why do you not invest?

- If you were offered a piece of advice on investment, what would be the main priorities for you (1 being the highest and 5 being the lowest importance)? Decrease/ elimination of risk, As high as possible returns, To get the returns in a short time period, To get the returns in a long time period, To start with the smaller amount of money.

Questions have been divided into three main areas - demographics, personal finance management and personal investment. Demographics included age, location, family status, marital status, employment status, monthly income, and financial education. Personal finance topic has been analysed by inquiring about expenditure, monthly savings, savings planning and preferences, whereas personal investment strategy related queries included the choice of investing or not, reasons for not investing, the selection of where to invest, self-evaluation of investment knowledge, and supposed investment plan preferences. The survey has been designed and delivered to the participant group via social media and personal contacts.

In conclusion, the methodology part of the research includes the fundamental reasons and tools of investing, the sample size of the research on female participants in Lithuania, survey structure and the main questions.

\section{Research Results}

It is now well established from the literature and methodology parts that differences among males and females exist in the investment and finance management area and plays a critical role in wealth inequality among genders. To further thoroughly research and obtain sufficient knowledge Lithuania's case analysis has been used for this study. The first step was to collect as much data as possible, and, in Lithuania's case, there were not many articles or statistics available in this area. Department of Statistics under the Government of the Republic of Lithuania has been contacted, and the information was received that currently there has been no official research done by this authority, and none of the data exists on the investors' profile, personal investment, or female investment decisions matters. The decision was made to use publicly available information and to conduct the research on personal investment peculiarities among genders in Lithuania, with emphasis on female investment strategies.

To compare the differences among male and female investment, pension, and financial stability areas, the study was conducted by "INVL Asset Management" and published on their website (Invalda, 2017). This research took place in 2017 and included 1011 Lithuanian residents between 18 and 75; it was most informative and thorough, besides including gender differences and priorities. The main topic that has been assessed during this research is the difference between female and male investment and pension choices. The main discovery presented by "Invalda" is that Lithuanian women investor's profile tends to be more conservative than men; additionally, females tend to choose to save rather than invest. The subject of pension has been discussed to substantiate these findings, and a summary of findings was presented. It concluded that a higher percentage of female participants $-48.5 \%$ stated that to keep living in dignity during their pension time, the compensation itself should be equal to the current salary, whereas $39.7 \%$ of the males expressed the same aspiration. Women also tend to lean towards the safer side while asked about savings management habits. The data from this survey has shown that in their opinion (33.5\% of respondents), people should start saving for their retirement from ages 19-25, and $8.1 \%$ of female questionnaire partakers suggested that the age should even be 18 . In this case, male participants were a bit more nonchalant and 19 to 25 years as the age point to start putting money aside for this purpose was chosen by $28.9 \%$ and $6.6 \% 18$ years old. However, the opinions almost coincide with starting to save for retirement at the age of 26-35 and continually differed on the oldest age to be 36-45 years old (chosen by $16.1 \%$ of males and $13.5 \%$ of females). The other important findings have been presented during this research are more women $(36.1 \%)$ than man $(32.7 \%)$ are expecting to be able to use money from their retirement or pension funds, majority of participants are planning to use the funds for their retirement from "Sodra" (females - $89.8 \%$ and males $-88.7 \%$ ), and $19.6 \%$ of women and $20.8 \%$ of men are planning to work during their retirement. The interesting fact is that more 
male than female participants plan to live from their savings once the retirement period comes $-35.5 \%$ and $30.9 \%$, respectively. Regarding the investment subject, females were presented as more restrained since $14.3 \%$ responded positively to the question of whether they invest; as a comparison, $18.7 \%$ of male respondents answered the same. Women investors could also be called more careful once it comes to the invested amount since more of them agreed that it consists of 20 EUR $-12.5 \%$, respectively 4.8 $\%$ of males choose the same option. Male investors preferred to start with 51 to 100 EUR investment funds $-37.5 \%$ and $27.1 \%$ of females. A similar percentage of participants declared that they invest 21 50 and 101-200 EUR per month.

The first set of analysis examined the overall distinctness among genders in financial and investment fields in Lithuania, whereas the second series of the study concentrates on Lithuanian women's personal finances and investment selections. Based on the results presented at Global Financial Literacy Survey (The Standard \& Poor's Ratings Services, 2015) in 2015, the key findings included the astonishingly low level of financial literacy among the worldwide participants, the surprising fact that inflation and numeracy were the most understood concepts. In contrast, the risk diversification was undeservedly neglected; moreover, the young people group was declared a vulnerable class, and the concentration should be placed on education programs dedicated to improving this group's financial knowledge and literacy. Lastly, the most related to this paperwork; hence, the most significant discovery women's financial literacy levels were lower than men. There was also mentioned that females had weaker financial skills despite the country's economy, age, education, or income.

It is important to develop the understanding of the Lithuanian female knowledge and self-perspective in finance and investment areas to clarify the idea on how to improve the current situation. To do so, the survey has been conducted, and the questions about financial literacy, financial education level, current employment status, salary, personal investment strategy and the reasons for not investing have been introduced. The question of how much knowledge one has in investment and finance areas in the survey revealed that self-evaluation on financial understanding, which also reflects confidence level of financial literacy grew in correlation to age growth; however, on average Lithuanian females evaluated their financial literacy as the medium level.

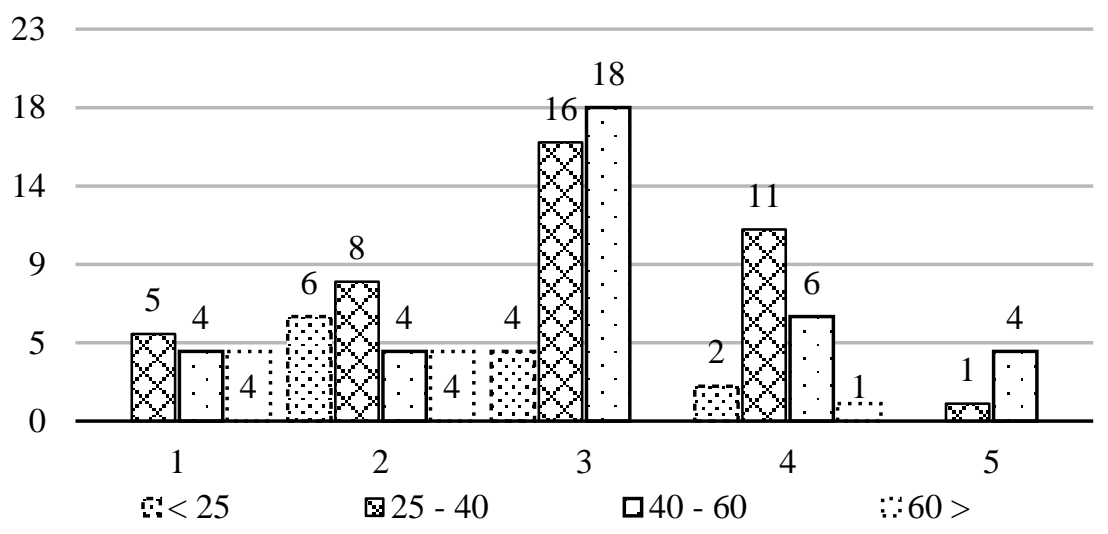

Fig 1. Self-evaluation of knowledge level in finance area by Lithuanian females (Source: created by author)

The next question asked the informants how they obtained their financial education. The summary of the answers revealed that around $27 \%$ of female participants have gained their understanding in finance and investment fields from their studies such as high school, Bachelors, or master's degrees, one participant, was a $\mathrm{PhD}$ holder in Economics. On the other hand, around $16 \%$ of all females were seeking advanced financial, economic, and investment literacy independently by reading magazines, books, or watching related videos either on top of their formal education or independently. Surprisingly, most 
survey participants (59\%) did not have any finance or investment related education; hence, profound knowledge about the subject.

The other demographical questions analysed Lithuanian females' employment and salary situation. When asked about the work status, most participants (69\%) responded to be working for the company, $16 \%$ owned an enterprise, $7 \%$ were retired, and $9 \%$ were studying. Regarding the monthly salary, $52 \%$ of the respondents replied to be earning $€ 1000$ - $€ 3000,37 \%$ and $11 \%-€ 1000$ and over $€ 3000$, respectively. Respondents were asked to indicate whether they are currently investing, and 53\% answered positively.

The most popular investment tools were life insurance, pension funds and real estate.

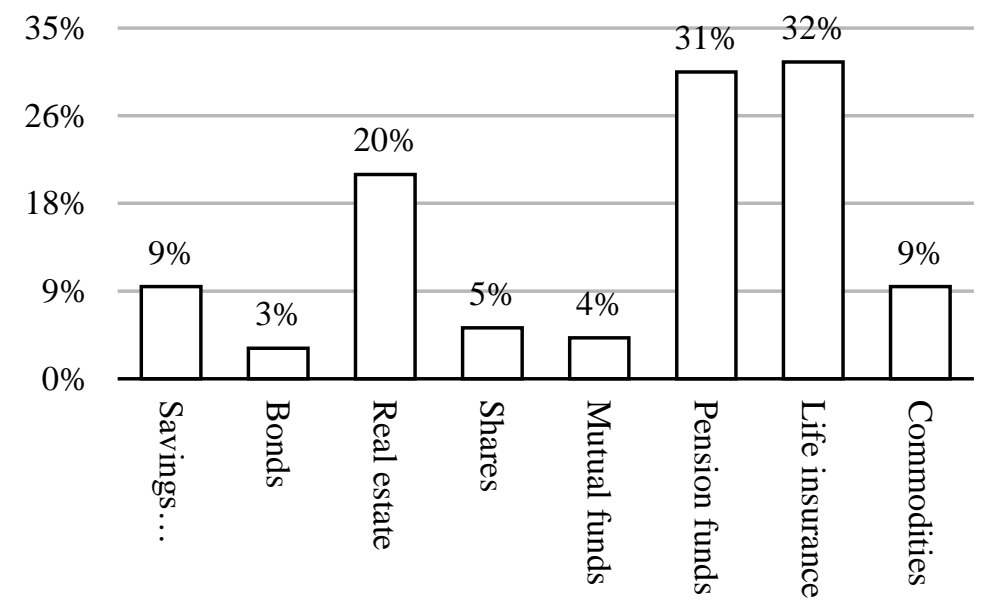

Fig 2. The investment options among females in Lithuania (Source: created by author)

As can be seen from the figure (Fig. 2) above, the least popular investment options among females in Lithuania are bonds, mutual funds, shares, commodities, and savings account. The second part of this personal investment management query implemented in the survey was why women in Lithuania do not invest. The responses have been presented in the figure below:

Figure 3 provides the summary of the replies from participants and what stands out is that $43 \%$ and 38 $\%$ answered not to have enough funds or knowledge about investment, and this being the main reason not to invest.

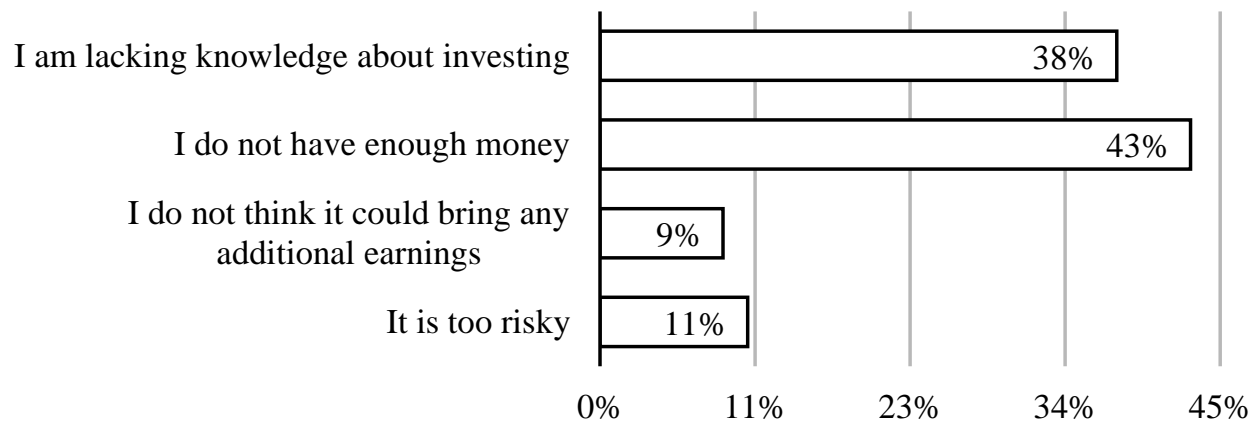

Fig 3. The reasons for not investing among Lithuanian females (Source: created by author) 
This section of the study was researching Lithuanian female investors profile and has shown that women are more conservative investors than men and rather choose to save more than invest, and this is mainly related to retirement planning and being cautious about the future. The other finding was related to the formal financial education and financial knowledge self-evaluation - in this section it was disclosed that respondents believe to be holding the average level of financial and investing understanding, only $27 \%$ out of all survey attendance had formal education related to finance and 59\% claimed to not have any financial knowledge at all. Regarding the monthly salary majority of participants earned $€ 1000$ - $€ 3000$, which could be seen as a sufficient amount for a possibility to raise spare funds for investment purposes. On the contrary, the current investment tool selection seems to be not fully explored, and the opportunities to exploit additional beneficial recourses are available; for example, bonds, stocks and commodities have been overlooked and could be a highly rewarding source of income if used in a proficient way. To summarise this section of the article, the most significant discovery established in this section of the study was that Lithuanian females chose not to invest due to the lack of additional funds, since investing is inseparable from the risk, and the shortage of financial knowledge, such as understanding investing processes and investment tools.

\section{Conclusions}

The research was done based on literature, reports, surveys, and statistical data. The primary objectives were to find out what the main peculiarities between males and females when it comes to personal investment strategy choices are. The main points revealed during this study were as follows:

- Men tend to invest more often than women, as females, in general, prefer to save rather than invest.

- Men are more likely to choose a higher-risk investment strategy and to be more confident in their investment ability even if they have less knowledge on the matter.

- Women tend to choose less risky investment strategies compared to men. The main factors of this phenomena are the influence of cultural, social, or psychological factors, low financial literacy level, differences in economic status, longer life expectancy, the lack of confidence when it comes to knowledge applied to the financial decisions.

- Lithuania's case analysis confirmed literature findings and the ideas of the other authors that have been introduced in the article that Lithuanian females lack financial and investment knowledge and understanding, are more conservative compared to man and prefer to save, and, if choose to invest, select safer investment options such as pension or life insurance funds, real estate, or savings accounts.

This is an important issue for further research, and the leading suggestions would be to concentrate on female education and respective financial and investment programs creation to improve the current situation by creating the method to encourage women to invest more and not to limit themselves by safe investment tools, but to create broader diversified personal investment strategies with the inclusion of bearing higher-risk, subsequently, benefiting from greater returns investment instruments. In Lithuania's case, this could be done by using countless opportunities to implement this project idea, the main being through various women organisations such as non-profit institutions like Women information centre (Moterų informacijos centras), Social Innovations Fund (Socialinių inovacijų fondas), Public Institution Equal Opportunity Development Centre, (Viešoji ịstaiga Lygiu galimybių plètros centras), Public Institution European Innovation Centre (Viešoji ịstaiga Europinių inovacijų centras), Knowledge Economic centre (Žinių ekonomikos forumas ), Association of the Third Age University (Trečiojo amžiaus universitetu (TAU) asociacija) and many others in line with collaboration with Lithuanian Ministry of Education and Science.

\section{References}

Australian Government Financial Literacy Foundation. (2008a). Financial literacy. Women understanding money (Report number ISBN: 978174207 648). Retrieved from https://financialcapability.gov.au/files/womenunderstanding-money.pdf 
Australian Government Financial Literacy Foundation. (2008b). Financial literacy. Women understanding money. Retrieved December 9, 2018, from https://financialcapability.gov.au/files/women-understanding-money.pdf

Australian Securities and Investment Commission. (2008). Australian investors: at a glance (Report Number 121). Retrieved from https://download.asic.gov.au/media/1344854/rep_121_Australian_investors_at_a_glance.pdf

Australian Security Exchange (2020). ASX Australian Investor Study 2020. Retrieved from https://www2.asx.com.au/blog/australian-investor-study/investor-profiles\#female-investors

Bajtelsmit, V. L., \& Bernasek, A. (1997). Why Do Women Invest Differently than Men? SSRN Electronic Journal. doi:10.2139/ssrn.2238

Bayyurt, N., Karışık V., \& Coşkun, A. 2015. Gender Differences in Investment Preferences. Retrieved from https://www.researchgate.net/publication/277313389.

Birtch, T.A., Au, K.Y., Chiang, F.F.T., \& Hofman, P. S. (2018). How perceived risk and return interacts with familism to influence individuals 'investment strategies: The case of capital seeking and capital providing behavior in new venture financing. Asia Pacific Journal of Management, Volume 35, Issue 2, 471-500. https://doi.org/10.1007/s10490-017-9525-0

Brown, A., Patten, P. (2018). The narrowing, but persistent, gender gap in pay. Pew Research Center. Retrieved from: http://leametz.pbworks.com/f/Gender pay gap has narrowed, but changed little in past decade.pdf

Charness, G., \& Gneezy, U. (2007). Strong Evidence for Gender Differences in Investment. SSRN Electronic Journal. 23 p. https://dx.doi.org/10.2139/ssrn.648735

Dickason, Z., Nel, I., Ferreira, S.J. 2017. GENDER: BEHAVIOURAL FINANCE AND SATISFACTION OF LIFE. Gender \& Behaviour, 15 (3), 2017, 9550-9559. 2017. Life Centre for Psychological Studies/Services, Nigeria.

Economy Watch. (2018). Investment Strategy, Guide to Investment Strategy. Retrieved from http://www.economywatch.com/investment/investment-strategy.html

European Union. (2018). 2018 Report on equality between women and men in the EU (Report number ISSN: 18312802). Retrieved from European Commision: doi:10.2838/168837

Farrell, L., Fry, T. R., \& Risse, L. (2016). The significance of financial self-efficacy in explaining women's personal finance behaviour. Journal of Economic Psychology, 54, 85-99. doi:10.1016/j.joep.2015.07.001

Felton, J., Gibson, B., \& Sanbonmatsu, D. M. (2003). Preference for Risk in Investing as a Function of Trait Optimism and Gender. Journal of Behavioral Finance, 4(1), 33-40. doi:10.1207/s15327760jpfm0401_05

Fidelity Brokerage Services LLC (2015) Money fit women study: Executive Summary. Retrieved from Fidelity Investments website: https://www.fidelity.com/bin-public/060_www_fidelity_com/documents/women-fitmoney-study.pdf

Finra Investor Education Foundation. (2016). Investors in the United States 2016 (Report Nr. 16_0388.1 — 12/16). Retrieved from https://www.usfinancialcapability.org/downloads/NFCS_2015_Inv_Survey_Full_Report.pdf

Gerrans, P., Moulang, C., Feng, J., \& Strydom, M. (2018). Individual and peer effects in retirement savings investment choices. Pacific-Basin Finance Journal, Volume 47, February 2018, 150-165. https://doi.org/10.1016/j.pacfin.2017.11.001

Hasler, A., \& Lusardi, A. (2017, July). The Gender Gap in Financial Literacy: A Global Perspective. Retrieved from https://gflec.org/wp-content/uploads/2017/07/The-Gender-Gap-in-Financial-Literacy-A-GlobalPerspective-Report.pdf

Hira T. K., Loibl C. (2008). Gender Differences in Investment Behavior. In J.J. Xiao (Eds), Handbook of Consumer Finance Research. New York: Springer.

Huang, X. (2018). Mark Twain's Cat: Investment experience, categorical thinking, and stock selection. Journal of Financial Economics. Volume 131, Issue 2, February 2019, 404-432. https://doi.org/10.1016/j.jfineco.2018.08.003

Hussain, S., Ali, S., Ibrahim, M., Balouch, W., Yousouf, M., Ghafoor, A. 2015. Impact of Women Behavior on Financial Decision Making. Global Journal of Management and Business Research: C Finance. Volume 15 Issue 1 Version 1.0 Year International Research Journal. Global Journals Inc. (USA) ISSN: 2249-4588. 
Invalda (2017). INVL: Turto valdymo grupè. Tyrimas: Moterys reiklesnès būsimai pensijai, o investuoti renkasi daugiau vyru Retrieved from: https://www.invaldainvl.com/1/1t/articles/articles/view/3244/tyrimas-moterysreiklesnes-busimai-pensijai-o-investuoti

INVL Asset Management. (2018). Lietuvoje vyrai dažniau investuoja, moterys - taupo ir planuoja. Retrieved from: https://www.invl.com/lit/lt/naujienu-centras/naujienos/256/lietuvoje-vyrai-dazniau-investuoja-moterystaupo-ir

Itkin, L. (2014). Every woman should know her options: Invest your way to financial empowerment. San Diego, CA: The Options Lady Press.

Jawaheer, B. M., \& Manual, V. (2016). Gender Differences in Investment Decision Making Among the Working Class of Mauritius. Imperial Journal of Interdisciplinary Research (IJIR), 2(9).

Lee, K., Miller, S., Velasquez, N. \& Wann, C. (2013) The Effect of Investor Bias and Gender on Portfolio Performance and Risk. The International Journal of Business and Finance Research, v. 7 (1) pp. 1-16, 2013. SSRN: https://ssrn.com/abstract=2148664

Lei, S. (2018). Single women and stock investment in individual retirement accounts. Journal of Women \& Aging. https://doi.org/10.1080/08952841.2018.1510241

Levine, J. P. (2019). Million-dollar women: The essential guide for female entrepreneurs who want to go big. London: Piatkus.

Liem, G. A., \& McInerney, D. M. (2018). Big theories revisited 2. Charlotte, NC: Information Age Publishing.

Macijauskas, L. (2012). Investavimo strategijos. Lietuvos investuotojy tyrimas. Retrieved from: https://www.synergyfinance.com/file/repository/news/pdf/Lietuvos_investuotoju_tyrimas_2013_01_.pdf

Malkiel, B. G. (2019). A random walk down Wall Street: The time-tested strategy for successful investing. New York: W.W. Norton \& Company.

McCarthy, N., McCarthy, N., \& Richter, F. (2018). Infographic: The Gender Pay Gap In Europe. Retrieved from https://www.statista.com/chart/13174/the-gender-pay-gap-in-europe/

Mclean, L. D., Guilford, J. P., \& Fruchter, B. (1979). Fundamental Statistics in Psychology and Education. Educational Researcher, 8(3), 22. doi:10.2307/1174363

Mittal, M., \& Vyas, R. (2009). Do Women Differ in Their Investment Information Processing Style? Indian Journal of Gender Studies, 16(1), 99-108. doi:10.1177/097152150801600105

Mottola, G. (2015). Finra Investor Education Foundation. Insights: Financial Capability. Retrieved from: https://www.finrafoundation.org/sites/default/files/A-Snapshot-of-Investor-Households-in-America_0_0_0.pdf

Nasdaq. (2019) The 10 Commandments of Investing. Retrieved from https://www.nasdaq.com/investing/10commandments-of-investing.stm

National Australia Bank Limited. (2018). Personal investments. Retrieved from NAB https://www.nab.com.au/personal/investments

Oprean, C. (2014). Effects of Behavioural Factors on Human Financial Decisions. Procedia Economics and Finance 16 (2014) 458 - 463. DOI: 10.1016/S2212-5671(14)00825-9

PayScale. (2018). The State of the Gender Pay Gap In 2018. Retrieve from PayScale: https://www.payscale.com/data/gender-pay-gap

Ravazzini, L., \& Kuhn, U. (2018). Inequality and Wealth: Comparing the Gender Wealth Gap in Switzerland and Australia. Feminist Economics Journal, Volume 24, Issue 4, 83-107. https://doi.org/10.1080/13545701.2018.1458202

Saris, W. E., \& Gallhofer, I. N. (2014). Design, Evaluation, and Analysis of Questionnaires for Survey Research (2nd ed.). Somerset: Wiley.

Shaikh, G. M., Karim Katpar, N., Kalhoro, M., Abro, Y. K., \& Phanwar, G. A. (2019). Do behavioral biases in gender differences affect investment decisions? Sociology International Journal, 3(4). doi:10.15406/sij.2019.03.00194

Siva, S. (2012). A study on Gender Difference in Investment Choice \& Risk-Taking. International Journal of 
Applied Research in BUSINESS ADMINISTRATION \& ECONOMICS. IJAR-BAE, 1(1), 01- 06.

Stanyer, P., \& Satchell, S. (2018). The Economist Guide to Investment Strategy 4th Edition: How to Understand Markets, Risk, Rewards, and Behaviour. New York: Public Affairs.

Statistics Lithuania (2017). Women and Men in Lithuania 2016. Retrieved from Statistics Lithuania:

Swenson, D. F. (2005). Unconventional success: A Fundamental Approach to Personal Investment. New York: Free Press.

Tengler, N. (2014). The Women's Guide to Successful Investing: Achieving Financial Security and Realising Your Goals(2014th ed.). New York: Palgrave Macmillan.

The Standard \& Poor's Ratings Services (2015, November 18). Global Financial Literacy Survey. Retrieved from https://gflec.org/initiatives/sp-global-finlit-survey/

Tyson, E. (2019). Personal finance for dummies ( $9^{\text {th }}$ edition). New York: John Wiley \& Sons.

United Nations. (2017). UNITED NATIONS DEVELOPMENT PROGRAMME. Human Development reports. Gender Inequality Index (GII). Retrieved from: http://hdr.undp.org/en/data

Walker, R. B., \& Walker, K. P. (2013). Personal finance: Building your future. New York, NY: McGrawHill/Irwin.

Westpac Banking Corporation. 6 steps to developing an investment strategy (2018). Retrieved from Westpac bank Australia: https://www.westpac.com.au/personal-banking/investments/the-share-market/investment-strategy/

World Health Organization (2018, May 15). Life expectancy. Retrieved from: https://www.who.int/gho/mortality_burden_disease/life_tables/situation_trends_text/en/ 